\title{
European Supreme Courts. A Portrait through History, red. A. A. Wijffels, C. H. van Rhee. Foreword by Baron Neuberger of Abbotsbury, President of the Supreme Court of the United Kingdom, Third Millennium Publishing, London 2013, 288 stron
}

Recenzowana praca jest pięknie wydanym wydawnictwem albumowym, mającym dodatkowo walory pracy naukowej o charakterze prawnoporównawczym. Jest pracą zbiorową, w której 28 autorów z Europy przedstawia dzieje sądów najwyższych w wybranych krajach europejskich. Pracę poprzedza ciekawie skonstruowane kalendarium, rozpoczynające się od kodyfikacji justyniańskiej, a zakończone powstaniem Międzynarodowego Trybunału Karnego w 2002 r. i Traktatem Lizbońskim z 2007 r. Następnie Alain Wijffels z Uniwersytetu w Lejdzie w obszernym szkicu European Legal History and the Diversity of Supreme Judicatures (s. 14-37) starał się przedstawić wspólne elementy w historii prawa w Europie oraz w organizacji sądów najwyższych. Wskazanie ich łączy się z prawem rzymskim, z ius commune oraz z wpływem najważniejszych kodyfikacji nowożytnej Europy.

Najbardziej obszerna I część publikacji ukazuje dzieje sądów najwyższych w poszczególnych państwach Europy. Przedstawiono dzieje tych instytucji na obszarze Włoch, Francji, Niemiec, Skandynawii, Szwajcarii, Hiszpanii i Portugalii, Rzeczypospolitej Obojga Narodów, Rosji, Niderlandów, Belgii, południowej Europy, Imperium Otomańskiego oraz Anglii i Szkocji. W tym kontekście należy odnotować interesujący szkic prof. Wacława Uruszczaka o Trybunale Koronnym i Litewskim. Niestety, z niewiadomych przyczyn zabrakło w książce miejsca dla dziejów polskiego Sądu Najwyższego w XX w., który przecież mógłby być wartościowym wkładem w dzieje współczesnego sądownictwa europejskiego. Znalazło się natomiast miejsce dla przedstawienia krótkiej przekrojowej historii sądów w Rosji, w tym - bardzo krótkiej - w Związku Radzieckim. Ich dzieje ilustruje - nie wiadomo, w jakim celu - wspólne całostronicowe zdjęcie prezesa Sądu Najwyższego Rosyjskiej Federacji Wiaczesława Lebiediewa z prezydentem Władimirem Putinem. Czy ma ono być dowodem ścisłej współpracy władzy sądowej z wykonawczą w Rosji?

Część II albumu poświęcona jest historii ponadnarodowych trybunałów i sądów w Europie w XX i XXI w. Przedstawiony jest m.in. Stały Trybunał Sprawiedliwości Międzynarodowej i Międzynarodowy Trybunał Sprawiedliwości w Hadze. Wywołuje to pytania natury terminologicznej. Prawdopodobnie zamiarem redaktorów było wykazanie ewolucji w postaci wzrostu znaczenia sądów międzynarodowych, ze szczególnym uwzględnieniem Europej- 
skiego Trybunału Praw Człowieka i Europejskiego Trybunału Sprawiedliwości. W odniesieniu do ETS słusznie jednak zauważono, że ewentualna supremacja tego sądu w przyszłości jest kwestionowana przez trybunały konstytucyjne państw członkowskich, poczynając od niemieckiego Trybunału Konstytucyjnego. Przyszła ewolucja Trybunału Sprawiedliwości UE jest w tym kontekście trudna do przewidzenia. Warto jednak uważnie obserwować orzecznictwo Trybunału na bazie Karty Praw Podstawowych UE.

Nie stoi to jednak na przeszkodzie, by uznać recenzowaną publikację za przydatną dla celów dydaktycznych, w tym zajęć dla studentów zagranicznych w ramach programu LLP Erasmus i innych programów dydaktycznych. Ciekawa forma publikacji niewątpliwie zadanie to ułatwia.

Piotr Fiedorczyk 